\title{
Fungal Enzymes in Decolorizing Paper Pulp
}

\author{
M. Suguna Devakumari* \\ Department of Agriculture, Karunya University, Karunya Nagar, Coimbatore -641114, \\ Tamil Nadu, India \\ *Corresponding author
}

\begin{tabular}{|c|c|}
\hline \multicolumn{2}{|r|}{ A B S T R A C T } \\
\hline & \multirow{6}{*}{$\begin{array}{l}\text { Wood pulps are the starting materials for the production of paper. During the kraft pulping } \\
\text { process, wood is cooked in sodium hydroxide and sodium sulfide, which dissolve much of } \\
\text { the lignin present in the fibres. The residual lignin can be removed by a subsequent } \\
\text { bleaching treatment with chlorine based chemicals. Besides chlorine, } \mathrm{ClO}_{2} \text {, oxygen, } \\
\text { hydrogen peroxide, ozone and acid washing are used for bleaching the kraft pulp. } \\
\text { However, environmental concerns lead to seek alternative ways to eliminate the use of } \\
\text { chlorine in bleaching. White rot fungi are the most attractive candidates for the removal of } \\
\text { residual lignin from wood pulps through biological means. Dechlorination of kraft pulp } \\
\text { containing bound chloride compounds with crude laccase enzyme from white rot fungi is } \\
\text { attempted in this study. In this study, the use of microbial enzymes to substitute chemical } \\
\text { bleaching of pulp was explored. Five days old fungal cultures of } P \text {. chrysosporium and } T \text {. } \\
\text { versicolor were inoculated into mineral salts media (N levels }-0.2 \% \text { and } 1 \% \text { and kept } \\
\text { under shaking at } 250 \text { rpm, at } 25-30^{\circ} \mathrm{C} \text {. Glass marbles were added to the media to prevent } \\
\text { fungal pellet formation which resulted in the growth of fragmented hyphal suspension. For } \\
\text { each treatment, } 100 \mathrm{~g} \text { of pulp was taken in autoclavable polypropylens bags with cotton } \\
\text { plugs and autoclaved at } 121^{\circ} \mathrm{C} \text { for } 15 \text { min. } 10 \text { ml of } 5 \text { days old culture suspension at } \\
\text { different dilutions according to treatment details were inoculated into the pulp samples and } \\
\text { incubated at room temperature }\left(25-30^{\circ} \mathrm{C} \text { ). Pulp samples were taken at } 5^{\text {th }} \text { and } 10^{\text {th }} \text { day of }\right. \\
\text { incubation and analysed for biobleaching efficiencies. The results of the biobleaching of } \\
\text { kraft pulps revealed that the undiluted liquid suspension culture of Phanerochaete } \\
\text { chrysosporium and Trametes versicolor with } 0.2 \% \mathrm{~N} \text { (nitrogen limited conditions) } \\
\text { efficiently degraded the lignin from all types of kraft pulps enhanced efficient bio } \\
\text { bleaching and brightening of the kraft pulp. }\end{array}$} \\
\hline Keywor & \\
\hline & \\
\hline Article Info & \\
\hline & \\
\hline & \\
\hline
\end{tabular}

\section{Introduction}

The growth of pulp based industries is an indication of increased development of a nation. As noted by Minor (1982), the pulp and paper industries have had three very difficult problems to control viz., the development of suitable methods for sulfite waste liquor recovery, elimination of malodorous and toxic sulphur compound emissions from the kraft pulping process and the elimination of BOD, COD and color from bleach plant effluents. The solutions to the bleach plant problems have proven to be the most difficult.

Arguably, this aspect of pulp production is the single greatest impediment to reduce and eliminate the environmental impact of pulp production processes. Hence alternate and 
environmentally benign technologies like enzymatic / biobleaching are highly sought after.

Wood pulps are the starting materials for the production of paper. In kraft pulping, wood is cooked in sodium hydroxide and sodium sulfide, which dissolve much of the lignin present in the fibres. The residual lignin can be removed by a subsequent bleaching treatment with chlorine based chemicals (Lorus, 1980). However, environmental concerns are leading scientists to seek alternative ways to eliminate, or at least reduce, the use of chlorine in bleaching. White rot fungi are the most attractive candidates for the removal of residual lignin from wood pulps through biological means. The ability of these organisms to depolymerize lignin substrates and to degrade lignin model compounds is well documented (Buswell and Oider, 1987; Kirk and Farrell, 1987). Schwantes and McDonough (1994) suggested that the ratio of chlorine to carbon in bleached kraft pulp effluent was an environmentally significant parameter and a predictor of toxicity.

White rot fungi produce unique extracellular oxidative enzymes that initiate the attack on nature's complex aromatic polymer, lignin. They are the heme containing peroxidases, lignin peroxidase (Lip) and manganese dependent peroxidase (Mn P) as well as the copper-containing phenol oxidase, laccase. In the presence of $\mathrm{H}_{2} \mathrm{O}_{2}, \mathrm{MnP}$ oxidizes $\mathrm{Mn}^{2+}$ to $\mathrm{Mn}^{3+}$, which can oxidize phenolic units in lignin (Bao et al., 1994). One of the most studied applications in the industry is the laccases-mediator bleaching of kraft pulp and the efficiency of which has been proven in mill-scale trials (Strebotnik and Hammel, 2000).Lignin peroxidases (LiP) compared with laccase, are the biocatalysts of choice for bleaching (Bajpai, 2004; Sigoillot et al., 2005) Roy and Archibald (1993) concluded that $T$. versicolor produces $\mathrm{MnP}$ which is important in delignification and bleaching of kraft pulp.

\section{Materials and Methods}

\section{Collection and maintenance of cultures}

The fungal cultures $P$. chrysosporium and $T$. versicolor were obtained from the culture collection of Department of Environmental Sciences, TNAU. The cultures were maintained in potato dextrose agar media.

\section{Experimental details}

\section{Preparation of liquid suspension cultures}

Five days old cultures of $P$. chrysosporium and $T$. versicolor were inoculated into mineral salts media ( $\mathrm{N}$ levels $-0.2 \%$ and $1 \%$ ) and kept under shaking at $250 \mathrm{rpm}$, at $25-30^{\circ} \mathrm{C}$. Glass marbles were added to the media to prevent fungal pellet formation which resulted in the growth of fragmented hyphal suspension (Kirkpatrick et al., 1989). The composition of mineral salts media is given in the following tables $1-4$.

\section{Treatment details}

Factor I - Microbial cultures

$\mathrm{C}_{1}$ - P. chrysosporium

$\mathrm{C}_{2}-$ T. versicolor

Factor II - dose - dilutions of liquid suspension cultures and $\mathrm{N}$ levels

$$
\begin{aligned}
& \mathrm{T}_{1} \text { - Pulp alone } \\
& \left.\mathrm{T}_{2} \text { - Pulp + undiluted suspension [N } 0.2 \%\right] \\
& \mathrm{T}_{3} \text { - Pulp }+2 \text { fold diluted suspension [N } 0.2 \% \text { ] } \\
& \mathrm{T}_{4}-\mathrm{Pulp}+4 \text { fold diluted suspension [N } 0.2 \% \text { ] } \\
& \left.\mathrm{T}_{5}-\text { Pulp + undiluted suspension [N } 1 \%\right] \\
& \mathrm{T}_{6}-\text { Pulp }+2 \text { fold diluted suspension [N } 1 \% \text { ] } \\
& \left.\mathrm{T}_{7}-\text { Pulp }+4 \text { fold diluted suspension [N } 1 \%\right]
\end{aligned}
$$




\section{Factor III - substrates - types of pulp}

$\mathrm{P}_{1}$ - Thickener pulp

$\mathrm{P}_{2}$ - Chlorine stage pulp

$\mathrm{P}_{3}$ - EP stage pulp

$\mathrm{P}_{4}$ - Hypo stage pulp

For each treatment, $100 \mathrm{~g}$ of pulp was taken in autoclavable polypropylens bags with cotton plugs and autoclaved at $121^{\circ} \mathrm{C}$ for 15 min. $10 \mathrm{ml}$ of 5 days old culture suspension at different dilutions according to treatment details were inoculated into the pulp samples and incubated at room temperature $\left(25-30^{\circ} \mathrm{C}\right)$. Pulp samples were taken at $5^{\text {th }}$ and $10^{\text {th }}$ day of incubation and analysed for biobleaching efficiencies.

\section{Characterization of bleached of pulp samples}

On the $5^{\text {th }}$ and $10^{\text {th }}$ days of incubation, the pulp samples were taken and analysed for kappa number (bleaching efficiency).

\section{Results and Discussion}

\section{Effect of fungal species on bio bleaching (kappa number)}

The kappa number reduction (bio bleaching) of the thickener stage pulp was $18.8 \%$ with Phanerochaete chrysosporium and $9.09 \%$ with Trametes versicolor compared to the uninoculated control. But for the chlorine stage pulp, Trametes versicolor brought about $4.54 \%$ reduction of kappa number while there was no reduction in kappa number under Phanerochaete chrysosporium. In case of the EP stage pulp, the enzymatic extracts of $P$. chrysosporium brought about $31.3 \%$ reduction and $T$. versicolor contributed to $25.0 \%$ reduction in kappa number. With reference to the Hypo stage pulp also, $P$. chrysosporium brought about maximum reduction of $33.3 \%$ compared to $T$. versicolor ( $22.2 \%$ reduction).

The fungus Phanerochaete chrysosporium recorded the lowest kappa number in all the pulp types except the chlorine stage pulp whereas, Trametes versicolor recorded the lowest kappa number in the chlorine stage pulp indicating its specific preference as suitable candidate for bleaching of chlorine stage pulp. This could be attributed to the activity of all the lignin degrading enzymes, viz., laccase, manganese peroxidase and ligninase which were the highest in the fungus Phanerochaete chrysosporium compared to Trametes versicolor indicating that $P$. chrysosporium was more efficient than $T$. versicolor in lignin degradation and bleaching of thickener, EP and hypo stage pulps. The chlorine stage pulp was efficiently delignified by Trametes versicolor which might be due to its tolerance to low $\mathrm{pH}$ and high dechlorination activity. This view has been supported by various workers (Kuwahara et al., 1984; Waldner et al., 1988; Orth et al., 1993).

\section{Effect of nutrient nitrogen optimization on bio bleaching (kappa number)}

The fungi were cultured under two different media fortified with nitrogen, at $1 \%$ Nitrogen level and $0.2 \%$ Nitrogen level. It was found that both the fungi $P$. chrysosporium and $T$. versicolor significantly reduced kappa number due to high lignin degradation when grown under $0.2 \% \mathrm{~N}$ level i.e, at $\mathrm{N}$ limited conditions, confirming that for enhancing bio bleaching efficiency, $\mathrm{N}$ at $0.2 \%$ itself is optimum. This was because lignin degradation or lignolytic activity is a secondary metabolic activity, which is initiated after the depletion of available nitrogen. 
Table.1 Kappa number of thickener pulp as influenced by enzyme extracts of different fungal cultures fortified with $\mathrm{N}$ nutrition

\begin{tabular}{|c|c|c|c|c|c|c|}
\hline \multirow{2}{*}{ Treatments } & \multicolumn{3}{|c|}{ D1 ( $5^{\text {th }}$ day of incubation $)$} & \multicolumn{3}{|c|}{ D2 (10 ${ }^{\text {th }}$ day of incubation $)$} \\
\hline & $\mathrm{C} 1(P . c)$ & $\mathrm{C} 2(T . v)$ & Mean & $\mathrm{C} 1(P . c)$ & $\mathrm{C} 2(T . v)$ & Mean \\
\hline $\mathrm{T}_{1}$ - Control & 22 & 22 & 22 & 22 & 22 & 22 \\
\hline $\mathrm{T}_{2}$-undiluted [N $\left.(0.2 \%)\right]$ & 19 & 19 & 19 & 16 & 18 & 17 \\
\hline $\mathrm{T}_{3}-2$ fold diluted $[\mathrm{N}(0.2 \%)]$ & 20 & 19 & 20 & 17 & 19 & 18 \\
\hline $\mathrm{T}_{4^{-}} 4$ fold diluted $[\mathrm{N}(0.2 \%)]$ & 20 & 21 & 21 & 17 & 20 & 19 \\
\hline $\mathrm{T}_{5^{-}}$undiluted $[\mathrm{N}(1 \%)]$ & 20 & 19 & 20 & 18 & 19 & 19 \\
\hline $\mathrm{T}_{6}-2$ fold diluted [N (1\%)] & 20 & 21 & 21 & 19 & 20 & 20 \\
\hline $\mathrm{T}_{7^{-}} 4$ fold diluted [N (1\%)] & 19 & 22 & 21 & 19 & 20 & 20 \\
\hline Mean & 20 & 20 & 20 & 18 & 20 & 19 \\
\hline
\end{tabular}

\begin{tabular}{|l|l|l|l|l|l|l|}
\hline & D & C & T & D x T & C x T & D x C x T \\
\hline SEd & 0.19 & 0.19 & 0.35 & NS & 0.50 & 0.70 \\
\hline CD $(0.05)$ & 0.38 & 0.38 & 0.72 & NS & 1.02 & 1.44 \\
\hline
\end{tabular}

Table.2 Kappa number of EP stage pulp as influenced by enzyme extracts of different fungal cultures fortified with $\mathrm{N}$ nutrition

\begin{tabular}{|c|c|c|c|c|c|c|}
\hline \multirow{2}{*}{ Treatments } & \multicolumn{3}{|c|}{ D1 ( $5^{\text {th }}$ day of incubation) } & \multicolumn{3}{|c|}{ D2 $\left(10^{\text {th }}\right.$ day of incubation $)$} \\
\hline & $\mathrm{C} 1(P . c)$ & $\mathrm{C} 2(T . v)$ & Mean & $\mathrm{C} 1(P . c)$ & $\mathrm{C} 2(T . v)$ & Mean \\
\hline $\mathrm{T}_{1}$ - Control & 16 & 16 & 16 & 16 & 16 & 16 \\
\hline $\mathrm{T}_{2}$-undiluted $[\mathrm{N}(0.2 \%)]$ & 10 & 11 & 11 & 9 & 10 & 10 \\
\hline $\mathrm{T}_{3}-2$ fold diluted $[\mathrm{N}(0.2 \%)]$ & 12 & 12 & 12 & 9 & 10 & 11 \\
\hline $\mathrm{T}_{4^{-}} 4$ fold diluted [N $\left.(0.2 \%)\right]$ & 12 & 12 & 12 & 10 & 12 & 12 \\
\hline $\mathrm{T}_{5^{-}}$undiluted $[\mathrm{N}(1 \%)]$ & 12 & 12 & 12 & 10 & 12 & 12 \\
\hline $\mathrm{T}_{6}-2$ fold diluted [N (1\%)] & 12 & 14 & 13 & 11 & 13 & 13 \\
\hline $\mathrm{T}_{7}-4$ fold diluted [N (1\%)] & 12 & 15 & 14 & 11 & 14 & 13 \\
\hline Mean & 12 & 13 & 13 & 11 & 12 & 12 \\
\hline
\end{tabular}

\begin{tabular}{|l|l|l|l|l|l|l|}
\hline & D & C & T & D x T & C x T & D x C x T \\
\hline SEd & 0.12 & 0.12 & 0.22 & 0.31 & 0.31 & NS \\
\hline CD $(0.05)$ & 0.24 & 0.24 & 0.45 & 0.64 & 0.64 & NS \\
\hline
\end{tabular}


Table.3 Kappa number of chlorine stage pulp as influenced by enzyme extracts of different fungal cultures fortified with $\mathrm{N}$ nutrition

\begin{tabular}{|c|c|c|c|c|c|c|}
\hline \multirow[b]{2}{*}{ Treatments } & \multicolumn{3}{|c|}{ C1 (P.chrysosporium) } & \multicolumn{3}{|c|}{ C2 (T.versicolor) } \\
\hline & $\mathrm{D} 1\left(5^{\text {th }}\right)$ & $\begin{array}{l}\text { D2 } \\
\left(10^{\text {th }}\right)\end{array}$ & Mean & $\mathrm{D} 1\left(5^{\text {th }}\right)$ & $\begin{array}{l}\text { D2 } \\
\left(10^{\text {th }}\right)\end{array}$ & Mean \\
\hline $\mathrm{T}_{1}$ - Control & 20 & 20 & 20 & 20 & 20 & 20 \\
\hline $\mathrm{T}_{2}$-undiluted $[\mathrm{N}(0.2 \%)]$ & 20 & 18 & 19 & 19 & 17 & 19 \\
\hline $\mathrm{T}_{3}-2$ fold diluted $[\mathrm{N}(0.2 \%)]$ & 20 & 19 & 20 & 19 & 18 & 19 \\
\hline $\mathrm{T}_{4^{-}} 4$ fold diluted [N $\left.(0.2 \%)\right]$ & 20 & 20 & 20 & 20 & 19 & 20 \\
\hline $\mathrm{T}_{5}-$ undiluted $[\mathrm{N}(1 \%)]$ & 20 & 19 & 20 & 19 & 18 & 19 \\
\hline $\mathrm{T}_{6}-2$ fold diluted [N (1\%)] & 20 & 19 & 20 & 20 & 18 & 19 \\
\hline $\mathrm{T}_{7^{-}} 4$ fold diluted [N (1\%)] & 20 & 20 & 20 & 20 & 19 & 20 \\
\hline Mean & 20 & 19 & 20 & 20 & 18 & 19 \\
\hline
\end{tabular}

\begin{tabular}{|l|l|l|l|l|l|l|}
\hline & D & C & T & D x T & C x T & D x C x T \\
\hline SEd & 0.19 & 0.19 & 0.35 & NS & NS & NS \\
\hline CD (0.05) & 0.38 & 0.38 & 0.71 & NS & NS & NS \\
\hline
\end{tabular}

Table.4 Kappa number of hypo stage pulp as influenced by enzyme extracts of different fungal cultures fortified with $\mathrm{N}$ nutrition

\begin{tabular}{|c|c|c|c|c|c|c|}
\hline \multirow[b]{2}{*}{ Treatments } & \multicolumn{3}{|c|}{ C1 (P.chrysosporium) } & \multicolumn{3}{|c|}{$\mathrm{C} 2$ (T.versicolor) } \\
\hline & $\mathrm{D} 1\left(5^{\text {th }}\right)$ & $\begin{array}{l}\mathrm{D} 2 \\
\left(10^{\text {th }}\right)\end{array}$ & Mean & $\mathrm{D} 1\left(5^{\mathrm{th}}\right)$ & $\begin{array}{l}\mathrm{D} 2 \\
\left(10^{\text {th }}\right)\end{array}$ & Mean \\
\hline $\mathrm{T}_{1}$ - Control & 9 & 9 & 9 & 9 & 9 & 9 \\
\hline $\mathrm{T}_{2}$-undiluted [N $\left.(0.2 \%)\right]$ & 5 & 6 & 6 & 3 & 5 & 5 \\
\hline $\mathrm{T}_{3}-2$ fold diluted $[\mathrm{N}(0.2 \%)]$ & 6 & 8 & 7 & 5 & 6 & 6 \\
\hline $\mathrm{T}_{4^{-}} 4$ fold diluted $[\mathrm{N}(0.2 \%)]$ & 6 & 8 & 7 & 5 & 7 & 7 \\
\hline $\mathrm{T}_{5^{-}}$undiluted $[\mathrm{N}(1 \%)]$ & 6 & 8 & 7 & 5 & 6 & 6 \\
\hline $\mathrm{T}_{6}-2$ fold diluted $[\mathrm{N}(1 \%)]$ & 7 & 9 & 8 & 6 & 6 & 7 \\
\hline $\mathrm{T}_{7^{-}} 4$ fold diluted [N $\left.(1 \%)\right]$ & 7 & 9 & 8 & 7 & 8 & 8 \\
\hline Mean & 7 & 8 & 7 & 6 & 7 & 7 \\
\hline
\end{tabular}

\begin{tabular}{|l|l|l|l|l|l|l|}
\hline & D & C & T & D x T & C x T & D x C x T \\
\hline SEd & 0.07 & 0.07 & 0.12 & 0.17 & 0.17 & 0.24 \\
\hline CD $(0.05)$ & 0.13 & 0.13 & 0.25 & 0.35 & 0.35 & 0.50 \\
\hline
\end{tabular}




\section{Media Composition}

\begin{tabular}{|l|l|l|}
\hline Chemicals & $1 \% \mathrm{~N}(250 \mathrm{ml})$ & $0.2 \% \mathrm{~N}(250 \mathrm{ml})$ \\
\hline Glucose & $2.5 \mathrm{~g}$ & 2.5 \\
\hline Peptone & $2.5 \mathrm{~g}$ & $0.5 \mathrm{~g}$ \\
\hline $\mathrm{K}_{2} \mathrm{HPO}_{4}$ & $0.5 \mathrm{~g}$ & $0.5 \mathrm{~g}$ \\
\hline $\mathrm{Mg} \mathrm{SO}_{4}$ & $0.125 \mathrm{~g}$ & $0.125 \mathrm{~g}$ \\
\hline $\mathrm{CaCl}$ & 0.025 & $0.025 \mathrm{~g}$ \\
\hline $\mathrm{KCl}$ & $0.125 \mathrm{~g}$ & $0.125 \mathrm{~g}$ \\
\hline $\mathrm{Kraft}$ pulp & $0.5 \mathrm{~g}$ & $0.5 \mathrm{~g}$ \\
\hline $\mathrm{pH}$ & 5.55 & $5-5.5$ \\
\hline
\end{tabular}

According to Jeffries et al., (1981) the lignolytic activity of $P$. chrysosporium appeared only after the primary growth phase, when carbon, nitrogen or sulphur limitation occurred.

Effect of enzyme concentration and days of incubation on bio bleaching of pulps (kappa number)

With reference to both the fungal species, the enzyme dose viz., the undiluted enzyme (10 $\mathrm{ml} 100 \mathrm{~g}^{-1}$ pulp) was found to be efficient in reducing the kappa number compared to 2 fold diluted and 4 fold diluted enzymes. The kappa number and the enzyme concentration were negatively related to each other. Similarly it was found that as the days of incubation advanced, more was the reduction in kappa number. Under both fungal enzymatic activity, kappa number was reduced by 1 unit on the $10^{\text {th }}$ day compared to that on the $5^{\text {th }}$ day for EP and Hypo stage pulps. For the chlorine stage pulp, the reduction of kappa number was by 2 units under T.versicolor and by 1 unit under P.chrysosporium, on the $10^{\text {th }}$ day of incubation. On the $10^{\text {th }}$ day of incubation kappa number reduction was 2 units higher than on the $5^{\text {th }}$ day under P.chrysosporium for thickener stage pulp. But the period of incubation had no effect on the kappa number reduction of thickener pulp treated with T.versicolor. Kabeya (1993) supported this view. He reported that increased enzyme dosage or reaction time increased the rate of lignin oxidation.

\section{References}

Bajpai, P. Biological bleaching of chemical pulps: Critical Reviews in Biotechnology., 249(1):1-58.

Bao, W., Y. Fukushima, K.A. Jensen, M.A. Moen and K. Hammel: FEBS lett., 354:297. (1994).

Buswell, J.A. and E. Odier.. Lignin biodegradation.: Crit.Rev.Biotechnol., 6:1-60. (1987).

Jeffries, T.W., S. Choi and T.K. Kirk. Nutritional regulation of lignin degration by Phanerochaete chysosporium: Appl. Env. Microbiol., 42: 290-296.(1981).

Kabeya, H. Measurement of free radicals in thermomechanical pulp containing water by electron spin resonance spectroscopy, Mokuzai Leakkaishi., 39: 86-90. (1993).

Kirk, T.K. and R.L. Farrell. Enzymatic "combustion", the chemical degradation of lignin: Annu.Rev.Microbiol., 41: 465-505.(1987).

Kirkpatrick, N., I.D. Reid, E. Ziomek, C. Ho and M.G. Paice. Relationship between fungal biomass production and the brightening of hardwood kraft pulp by Coriolus versicolor: Appl. Env. 
Microbiol., 55: 1147-1152. (1989).

Kuwahara, M., J.K. Glenn, M.A. Morgan and H.H. Gold. Separation and characterization of two extracellular $\mathrm{H}_{2} \mathrm{O}_{2}$ dependent oxidases from lignolytic cultures of Phareochaete chrysosporium.: FEBS Lett., 169: 247250. (1984).

Loras, V. Bleaching of chemical pulps. In: J.P. Casy 9edn, pulp and paper chemistry and chemical technology, John Wiley and Sons, Inc. New York, $3^{\text {rd }}$ ed., 1: 663-702 (1980).

Minor, J. Pulp. In: Volume 19. Grayson, M. (Ed.). Kirk-Othmer Encyclopedia of Chemical Technology. $3^{\text {rd }}$ Ed. John Wiley \& Sons, New York, pp. 379-419. (1982)

Orth, B.A., D.J. Royse and M. Tien. Ubiquity of lignin degraded peroxidases among various wood-degrading fungi: Appl. Env. Microbiol., 59: 4017-4023.(1993).
Roy, B.P. and F, Archibald. Effects of kraft pulp and lignin on Trametes versicolor carbon metabolism. Appl. Environ. Microbiol., 59: 1855-1863. (1993).

Sigoillot, C., S. Camarero, T. Vidal, E. Record, M. Asther, M. Pérez-Boada, M.J. Martínez, J.F. Colom and A.T. Martínez.. Comparison of different fungal enzymes for bleaching highquality paper pulps: Journal of Biotechnology., 115(4):333-343.(2005)

Strebotnik, E. and K.E. Hammel. Degradation of nonphenolic lignin by the laccase/1hidroxybenzotriazole system: Journal of biotechnology., 81(2): 179188. (2000).

Waldner, R., S. Matti, A. Leisola and A.Fiechter. Comparison of lignolytic activities of selected white rot fungi.: Appl. Microbial Biotechnol, 29: 400407.(1988).

\section{How to cite this article:}

Suguna Devakumari, M. 2017. Fungal Enzymes in Decolorizing Paper Pulp. Int.J.Curr.Microbiol.App.Sci. 6(11): 2873-2879. doi: https://doi.org/10.20546/ijcmas.2017.611.339 